\title{
Fra inspiration til litterært mødested
}

\author{
Litteratursiden i de fire rum
}

\section{Af Lise Vandborg og Astrid Bjørnskov Thorhauge}

\begin{abstract}
De danske bibliotekers website om skønlitteratur Litteratursiden.dk har i takt med den digitale udvikling og de moderne kommunikationsformer udviklet sig fra at være en envejs-kommunikerende vidensportal til at være et forum, hvor brugerne kan dele oplevelser og viden, søge inspiration og information og møde andre litteraturinteresserede. I 2009 blev Litteratursiden således relanceret i en 2.0 version, hvor brugerinvolvering blev en vigtig del af konceptet. I denne artikel diskuteres Litteratursidens udvikling med afsæt i 4-rumsmodellen som præsenteres i rapporten Folkebibliotekerne $i$ videnssamfundet (Styrelsen for Bibliotek og Medier 2010), og der gives indledningsvis en introduktion til, hvordan Litteratursiden 2.0 imødekommer et stigende behov for at være en del af et virtuelt fællesskab.
\end{abstract}

\section{Brugernes net}

Web 2.0 er som bekendt en diffus størrelse men forsøgt defineret af bl.a. Tim Berners-Lee ${ }^{1}$ som " $a$ collaborative medium, a place where we [could] all meet and read and write ${ }^{\prime 2}$. Ud fra denne tankegang er mange nye websites opstået, og det er vist sikkert at sige, at ideen om det brugerskabte indhold er kommet for at blive.

\author{
Lise Vandborg, chefredaktør på Litteratursiden \\ (lva@aarhus.dk) \\ Astrid Bjørnskov Thorhauge, redaktionsmedarbejder \\ påLitteratursiden (astridbt@gmail.com)
}

I takt med udviklingen af 2.0 har måden hvorpå vi bruger internettet også udviklet sig. Web 2.0 kan siges at indebære en demokratisering af viden, idet vi, som Berners-Lee formulerer det, alle har mulighed for både at modtage og bidrage med viden, oplevelser og ideer. Et fænomen som Wikipedia er naturligvis indbegrebet af denne demokratisering: den enkelte brugers viden er som udgangspunkt lige så værdifuld som 'eksperternes'.

I forlængelse af Web 2.0's udvikling er begrebet virtuelle fcellesskaber blevet en vigtig forståelsesramme for den online-baserede virkelighed, som fylder mere og mere i den moderne dagligdag. Howard Rheingold, kritiker, forfatter og underviser, er ophavsmand til betegnelsen "The Virtual Community"3, der dækker over det paradigmeskifte, som fællesskabet som institution har været udsat for - fra den fysiske til den virtuelle verden. Han argumenterer for, at mennesket som væsen er så socialt anlagt, at fællesskabet som sådan aldrig vil forsvinde. Menneskets trang til at spejle sig i andre vil overleve den digitale tidsalders individualisering. Men fællesskabet undergår naturligvis en forandring i transformeringen. I takt med at de uformelle offentlige rum, som markedspladsen, forsamlingshuset osv., opløses, søger mennesker sammen i de virtuelle fællesskaber for her uformelt at dele holdninger, indsigter og ideer med hinanden. Således danner de virtuelle fællesskaber platforme for uafhængige speaker's corners i alle hjørner af cyperspace. Den menige brugers stemme høres, diskuteres og spejles af andre brugere. Nettets demokratiske funktion er så at sige blevet for omfat- 
tende til, at man kan overlade indholdet til eksperterne, idet et "like" på Facebook fra en ven kan blive en ligeså valid kvalitetssikring som fx en avisanmeldelse:

"The combination of free expression, lack of central control, many-to-many communication access, and volunteer effort has created a new kind of social organization". (Rheingold, Howard: The Virtual Community, p.10)

Den nye sociale organisation er altså baseret på den enkeltes deltagelse og på modtagerens efterhånden sideordnede vurdering af budskaber fra både "menige" og "professionelle". En undersøgelse blandt Litteratursidens brugere viser i den forbindelse, at en overvægt af de der bruger sitets indhold, ikke skelner mellem brugerskabt og redaktionelt indhold. ${ }^{4}$

Manuel Castells, professor i sociologi, viderefører tanken om de virtuelle fællesskaber og undersøger den måde, hvorpå de nye netværk dannes. ${ }^{5}$ Han er overbevist om, at de sociale netværk på internettet bliver den dominerende form for socialisering i det 21. århundrede. Castells er optaget af de interessebaserede fællesskaber som erstatning for den gammeldags, geografibaserede form for community, hvor de nye netværk i samfundet bliver mere og mere baseret på, hvor den enkeltes interesse og viden befinder sig, frem for hvor han/hun bor. Derudover vil der kunne dannes nye netværk på tværs af de gamle, og brugerne vil kunne finde åndsfæller inden for selv den smalleste niche. Yderligere vil individets behov for at udtrykke sig blive imødekommet i disse åbne fællesskaber, i et samfund, hvor netop 'den performative handling' er vejen til at skabe sin identitet. ${ }^{6}$

Et virtuelt fællesskab kan altså fungere som et mødested, hvor alle kan lytte og tale - og blive hørt. Et mødested hvor ens interesse er omdrejningspunktet, og hvor alle - også de som i et fysisk fællesskab måske før har været marginaliseret - kommer til orde på et ligeværdigt niveau. Fællesskabet er altså baseret på, at medlemmerne alle har lige ret til at bidrage og samtidig kan blive inspireret af, loere af og møde andre ligesindede medmennesker. Netop disse nøgleord beskriver den demokratiske tendens på nettet, og danner ligeledes grundtanken for det nye bibliotekssyn som præsenteres i rapporten Folkebibliotekerne $i$ videnssamfundet (Styrelsen for Bibliotek og Medier 2010; se nedenfor). Litteratursiden lancerede i for- længelse af denne tankegang i 2009 en 2.0 version, hvor brugerdeltagelsen blev helt afgørende og der for alvor blev sat skub i blogs og anmeldelser skrevet af brugerne.

\section{Ny model for bibliotekerne}

Siden slutningen af 90'erne har den samfundsmæssige kontekst og dermed bibliotekernes samfundsmæssige legitimitet ændret sig. Pga. disse forandringer har en gruppe forskere i rapporten Folkebiblioteket $i$ videnssamfundet (Styrelsen for Bibliotek og Medier 2010) udviklet en ny '4-rumsmodel' for folkebibliotekerne, som medtænker de udfordringer, samfundsudviklingen stiller bibliotekerne overfor, og som viser de muligheder, bibliotekerne har for at opfylde brugernes behov i det senmoderne samfund. Ifølge modellen er det bibliotekernes centrale opgave i videnssamfundet at understøtte følgende fire formål:

- Erkendelse/erfaring

- Engagement

- Empowerment

- Innovation

De to første formål handler om at styrke individets erkendelse, erfaring og engagement i dets søgen efter mening og identitet, mens de to sidste formål i højere grad har fokus på samfundsmæssige mål. Empowerment handler om udviklingen af ressourcestærke borgere, mens det afgørende $\mathrm{i}$ innovation er at give nye svar og at udvikle helt nye koncepter, metoder eller kunstneriske udtryk (Styrelsen for Bibliotek og Medier 2010, s. 91):

- Læringsrummet er baseret på at opdage og lære nyt

- Inspirationsrummet er baseret på oplevelser

- Møderummet er baseret på deltagelse

- Det performative rum er betegnelsen for kreativt skabende aktiviter, der udfoldes af brugerne

Modellen opstiller de forskellige mulige rum eller universer, som bibliotekernes brugere kan befinde sig og agere $\mathrm{i}^{7}$. Modellen peger dermed også på de muligheder, Litteratursiden både i det virtuelle og $\mathrm{i}$ det fysiske rum skal give brugerne for selv at opleve, opdage, deltage og skabe indhold. Med Litteratursiden.2.0 har sitet åbnet for brugerinvolverende aktiviteter, og det er i dette perspektiv interessant at se på, hvordan Litteratursiden.dk kan inspirere til og styrke 


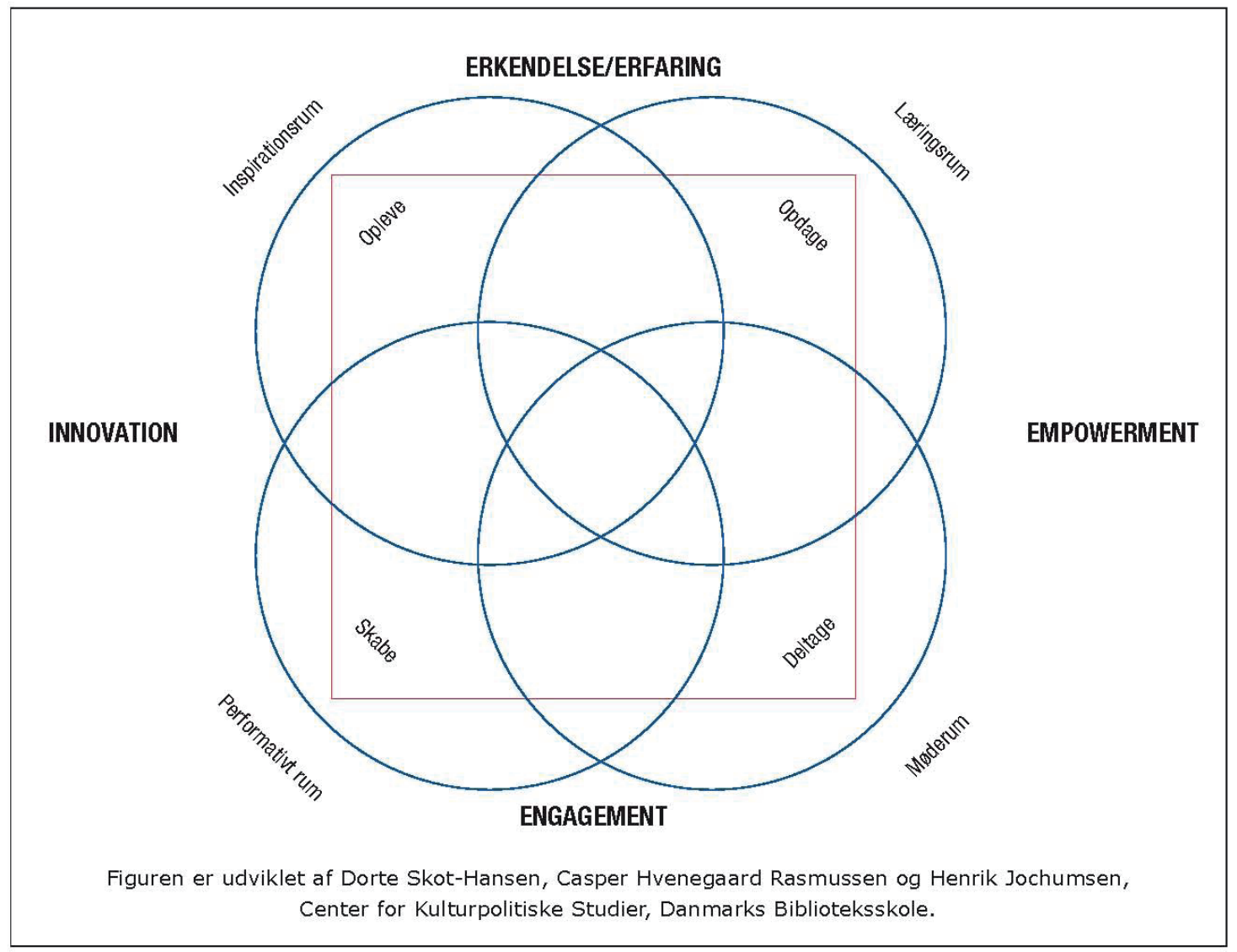

kreativiteten og innovationen i samfundet, netop ved at tilbyde et virtuelt fællesskab.

\section{Fra inspiration til modested, læring og perfor- mance}

Den oprindelige version af Litteratursiden, som blev lanceret i 2002, var baseret på en traditionel envejskommunikation, hvor indholdet til sitet blev skrevet og produceret af bibliotekarer eller andre professionelle skribenter med tilknytning til Litteratursiden og bibliotekerne. Brugerne havde allerede fra $2006 \mathrm{mu}-$ lighed for at tilføje kommentarer til indholdet, men der blev ikke i særlig stor udstrækning opfordret til denne mulighed.

Derfor lanceredes Litteratursiden i 2009 i en ny version, Litteratursiden 2.0. Ønsket var at udvikle en mere brugerinddragende version af Litteratursiden, hvor brugerne ikke alene havde mulighed for at kommentere på indlæg skrevet af professionelle men også for selv at bidrage med anbefalinger, blogs og deltage i læseklubber m.m.. Sitet kombinerer således bibliotekets traditionelle litteraturformidling af høj kvalitet med brugerskabt indhold, dvs. at sitet både rummer transaktionelle og relationelle ydelser. Henholdsvis et orange og et blåt ikon markerer, om indholdet er skrevet af Litteratursidens skribenter eller af brugerne, så der er mulighed for at skelne mellem de forskellige typer indhold, ligesom alt indhold i øvrigt er under redaktionelt opsyn.

Betragtes Litteratursiden i lyset af 4-rumsmodellen kan de fleste tilbud placeres i inspirationsrummet. Den oprindelige version af Litteratursiden var næsten udelukkende i inspirationsrummet, samt i nogen grad i læringsrummet når brugerne søgte oplysninger og fakta. Især sitets literære analyser, som bliver anvendt i stor udstrækning i danskundervisningen i gymnasiet, hører ind under læringsrummet. Derudover placerer læseklubbernes bogdebatter, hvor brugerne diskuterer bøger i det digitale rum, også sitet i møderummet. Med Litteratursiden 2.0 og muligheden for at producere indhold som for eksempel debatterende blogs og anmeldelser, at deltage i litterære debatter og som noget nyt også at deltage i aktiviteter 
som for eksempel debatarrangementer i det fysiske rum rækker Litteratursiden nu ind i det performative rum, da brugeren inddrages i aktiviteter og selv er med til at skabe indhold.

Der vil desuden være potentiale for at udvide det performative rum i kraft af at de nye veje, litteraturen bevæger sig på, som oftest befinder sig hinsides den fysiske bog. Her tænkes særligt på den eksperimenterende digitale litteratur og performancelitteratur. Bibliotekerne står i det hele taget over for en ny opgave i forhold til formidlingen af denne litteratur over for borgerne. Det vil være oplagt for Litteratursiden at gå ind i denne formidlingsopgave og samtidig styrke det performative rum på sitet ved for eksempel at vise eksperimenter med digital litteratur og performance litteratur. Det skal i denne sammenhæng nævnes, at Litteratursiden er samarbejdspartner på projektet "Litteraturen finder sted ${ }^{8}$ " $\mathrm{og}$ via videoer på sitet vil vise eksempler på performance litteratur. (Jf. artiklen af Lise Kloster Gram i forrige nummer af dette tidsskrift.)

\section{Simultane rum}

Mens den oprindelige version af Litteratursiden primært var i inspirationsrummet, er den nyere version altså til stede i alle fire rum, og netop der hvor brugerne har mulighed for at være i flere rum samtidig, sker det interessante, som det også fremgår af rapporten Folkebibliotekerne $i$ videnssamfundet:

"Ligesom kernen i folkebibliotekerne måske netop er koblingen mellem oplysning, uddannelse og kulturel aktivitet er det sikkert også i overgangen mellem eksempelvis lærings- og møderum, at der skabes unikke ydelser". (Styrelsen for Bibliotek og Medier 2010, s. 63)

Litteratursidens læseklubber bevæger sig i dette flydende felt mellem læring og mødested, da deltagerne mødes virtuelt og diskuterer, og der i denne dialog om bøger opstår læring. Mange deltagere giver således udtryk for, at de har fået ny erkendelse i dialogen. Dette gælder i øvrigt også for flere forfattere, som har deltaget i dialogen om deres bøger. Læseklubberne handler om involvering og om at skabe et fællesskab omkring læsningen, og her, hvor dialogen foregår i et åbent virtuelt fællesskab, får brugeren således også aktiveret sit performative jeg via den direkte og ikke-hierakiske meningsudveksling.
Læringsrummet og møderummet er desuden blevet forstærket med Litteratursidens seneste satsning på debatterende faglitteratur i samarbejde med DR. Målet har været at formidle faglitteratur i både det digitale og det fysiske rum, dels via en læseklub på Litteratursiden, dels via debatarrangementer med fagbogsforfattere på bibliotekerne. Med flere og flere genrehybrider og mere og mere flydende grænser mellem fag- og skønlitteratur har det været en naturlig del af sitets udvikling at bevæge sig ind i faglitteraturen. Fagbøger er i stigende grad toneangivende i den offentlige debat, og bibliotekerne er med dette projekt med til at ruste borgerne til at tage del i denne debat og dermed styrke den demokratiske proces. I lyset af 4-rumsmodellem kan man sige, at projektet er med til at styrke empowerment hos borgerne, eftersom de får styrket muligheden for at deltage aktivt i samfundsdebatten.

\section{Litteratursiden i Danskernes Digitale Bibliotek}

Faglitteraturen er også interessant i det kommende Danskernes Digitale Bibliotek ${ }^{9}$, eftersom det helt afgørende i det Digitale Bibliotek er koblingen af indhold med andet relevant indhold for brugerne. Denne kobling vil ofte gå på tværs af skøn- og faglitteratur. Den flydende grænse mellem genrerne og crossovers forstærker tendensen yderligere.

Litteratursiden giver via Open Source muligheder for at udveksle data med andre websites, hvilket er en forudsætning for at blive en del af Danskernes Digitale Bibliotek. Bibliotekernes formidling på internettet skal ses på baggrund af, at brugerne kan få adgang til de digitale medier uafhængigt af deres fysiske placering, og bibliotekernes formidling kan derfor ikke længere blot tage udgangspunkt i den lokale materialesamling. Der er hård konkurrence på internettet, og biblioteket må derfor indtage en mere aktiv rolle i formidlingen og kan ikke forvente, at brugeren selv opsøger bilioteket.

Samtidig er det via formidlingen, herunder kvalitetsvurdering af materialerne, at bibliotekerne adskiller sig fra de kommercielle tjenester på internettet.

Dermed er fokus rykket fra samlingen til brugeren, ligesom bibliotekerne allerede for mange år siden flyttede fokus i det fysiske bibliotek fra at stille materialer til rådighed til at formidle dem. Dette skred 
afspejler sig også i bevægelsen fra den oprindelige version af Litteratursiden til 2.0-versionen.

Denne udvikling blev fremhævet allerede i 2003 i en rapport med titlen Enviromental Scan: Pattern Recognition (Wilson 2003). Her analyseres bibliotekets rolle allerede bl.a. med afsæt i brugerens perspektiv, som er karakteriseret ved et personligt "informationsmiljø". Den enkelte bruger vil i stigende grad personalisere sin internetadfærd, også i form af apps, og det vil være nødvendigt at give brugeren så let adgang til individuelt relevant information som muligt og samtidig at tilbyde brugeren mulighed for selv at bidrage.

I rapporten betones det, at biblioteket må spille en rolle i dette informationsmiljø, fordi det er forudsætningen for, at biblioteket opleves som relevant. Bibliotekets udfordring sættes på spidsen ved at det ikke længere er indholdet, men konteksten som det vigtigste for brugeren. Der må skabes sammenhæng i information ved at koble den til anden information og sætte den i en bredere sammenhæng. En af måderne til at opnå dette er at lade brugerne bidrage med kontekst i form af indlæg og relevante links og ved at facilitere interaktion mellem brugerne. Således bliver Litteratursidens indhold langt mere meningsfyldt og brugbart, når det dukker op i de rette sammenhænge for brugeren og bliver koblet til andet indhold inden for samme emne.

Derfor er det afgørende, at Litteratursiden bliver synlig i brugernes informationsmiljø, når det er relevant. Samtidig bliver der stort fokus på, hvordan sitet kan understøtte bibliotekerne, når de ikke længere i så høj grad er baseret på fysiske materialer ved for eksempel at give brugerne adgang til lån af digitale materialer som f.eks. e-bøger. Desuden tilbydes indhold fra Litteratursiden til storskærme, ikke blot på bibliotekerne men også andre steder i det offentlige rum. Som det fremhæves i rapporten Folkebibliotekerne $i$ videnssamfundet, er det vigtigt, at bibliotekerne bevæger sig uden for biblioteksrummet - ud til brugerne hvor de er - hvad enten det er i det digitale rum eller det fysiske rum. Det vil også være interessant at kunne koble de virtuelle fællesskaber med det fysiske rum, fx i form af en kombineret debat på sitet omkring aktuelle samfundsdebatterende bøger og så muligheden for at opleve forfatteren/debattøren live i sit nærområde. Herigennem bliver bibliotekets fysiske rum aktualiseret via det digitale.

\section{Ud til brugerne hvor de er}

Litteratursiden er for at nå ud til brugerne i færd med at udvikle en app med boganmeldelser mm, så der er mulighed for at tilgå sitet via mobile enheder. Undersøgelser viser, at revolutionen inden for mobiltelefonmarkedet bliver større end den, vi har set i forhold til internettet. Tendensen på internettet bevæger sig hastigt mod en individualisering, hvor den enkelte brugers specifikke interesser er tilgængelige på smartphones og iPad osv. via apps. Det vil være oplagt, at Litteratursiden leverer målrettede anbefalinger tilpasset den enkelte brugers læseprofil, så brugerne fx kan deltage i læseklubdebatter via mobilen, samt giver brugeren mulighed for at få inspiration til ny læsning eller oplevelser simultant med, at de befinder sig på biblioteket.

Litteratursiden er under konstant udvikling, og det er interessant at undersøge og udvikle koblingen mellem netop det digitale og det fysiske rum. Derudover bliver en kommende relancering af Litteratursiden tænkt sammen med udviklingen i bibliotekernes digitalisering og vil derfor indgå i den infrastruktur i Danskernes Digitale Bibliotek, som kommer til vil forbinde bibliotekernes digitale indhold. Dermed bliver Litteratursidens indhold frem over tilgængeligt overalt i bibliotekernes flow af digital formidling.

Samtidig vil den nye version af sitet blive skræddersyet til at kunne opfylde brugerens behov for at opdage nyt, blive inspireret, skabe nyt indhold og deltage i debatter og arrangementer sammen med andre brugere - lige præcis hvor og når det passer den enkelte bruger.

\section{Noter}

1. Sir Timothy John "Tim" Berners-Lee er den britiske psykiater, computer forsker og MIT professor, som er krediteret for at have opfundet 'The World Wide Web'.

2. Berners-Lee: http://news.bbc.co.uk/2/hi/techno$\operatorname{logy} / 4132752 . s t m$

3. Rheingold, Howard: The Virtual Community, 1993, MIT Press

4. Gothen, Isabella (2011). Brugerne på Litteratursiden.dk. Roskilde Bibliotekerne. 
5. Castells, Manuel (2001). The Internet Galaxy. Oxford: Oxford University Press

6. Castells taler om begrebet "identitetsløse individer", som dækker over den enkeltes søgen efter identitet gennem den performative handling frem for gennem statiske størrelser som fx nationalitet. (Castells, Manuel: The Power of Identity, 1996, Blackwell Publishing)

7. Ibid., p. 47-49

8. "Litteraturen finder sted" er et projektsamarbejde mellem Aarhus og Roskilde biblioteker, som undersøger bibliotekernes rolle i forhold til litteraturen i det udvidede felt (www.netlitteratur.dk).

9. http://www.bibliotekogmedier.dk/biblioteksomraadet/fokusomraader/udvikling-af-det-digitalebibliotek/

\section{Referencer}

Castells, M (2001). The Internet Galaxy. Oxford: Oxford University Press
Castells, M (1996). The Power of Identity. London: Blackwell Publishing

Gothen, I (2011). Brugerne på Litteratursiden.dk. Roskilde Bibliotekerne.

Rheingold, H (1993). The Virtual Community. Cambridge (Mass.): MIT Press

Skot-Hansen, D, Hvenegaard Rasmussen, C. og Jochumsen, H (2010). Folkebibliotekerne $i$ vidensamfundet. Rapport udarbejdet af Udvalget om folkebibliotekerne $i$ vidensamfundet for Styrelsen for Bibliotek og Medier.

Wilson, A (red.) (2003). The OCLC Enviromental Scan: Pattern Recognition

http://www.bibliotekogmedier.dk/biblioteksomraadet/fokusomraader/udvikling-af-det-digitale-bibliotek/

http://www.netlitteratur.dk 